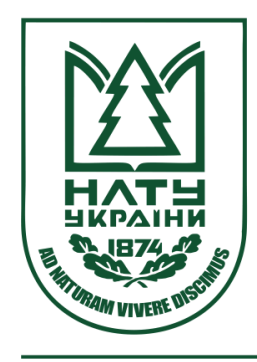

Науковий вісник НлтУ України Scientific Bulletin of UNFU

https://nv.nltu.edu.ua

https://doi.org/10.15421/40280608

$@ \bowtie$ Correspondence author

Article received 15.06.2018 p.

Article accepted 25.06.2018 p.

N. Y. Horbenko

УДК 582.688.4:581.162

nata.horbenko@gmail.com

Н. В. Скрипченко ${ }^{1}$, О. І. Дзюба ${ }^{1}$, Л. М. Короткіх ${ }^{2}$, Н. Є. Горбенко ${ }^{3}$, Н. В. Нужина ${ }^{4}$

${ }^{1}$ Національний ботанічний сад ім. М. М. Гришка, НАН України, м. Київ, Україна ${ }^{2}$ Інститут фізико-органічної хімії ім. Л. М. Литвиненка, НАН України, м. Київ, Україна

${ }^{3}$ Наиіональний лісотехнічний університет Украӥни, м. Львів, Україна

${ }^{4}$ Навчально-науковий иентр "Інститут біології та медииини" КНУ ім. Тараса Шевченка, м. Київ, Украӥна

\title{
ІДЕНТИФІКАЦІЯ СТАТІ РОСЛИН АКТИНІДІЇ ГОСТРОÏ (ACTINIDIA ARGUTA (SIEBOLD \& ZUCC.) PLANCH. EX MIQ.)
}

\begin{abstract}
Актинідія - це дводомна культура, і для забезпечення високої продуктивності її насаджень на ділянках необхідно одночасно висаджувати чоловічі та жіночі рослини у співвідношенні 1 до 5-7. Сортові жіночі рослини для насаджень одержують лише способом вегетативного розмноження, тоді як чоловічі рослини-запилювачі можуть бути як вегетативного, так і насіннєвого походження. Численні дослідження свідчать, що саме сіянці краще пристосовуються до нових умов зростання, вирізняються вищою адаптивною здатністю, підвищеною стійкістю до негативних чинників навколишнього середовища порівняно з вегетативно розмноженими рослинами. За літературними даними, вихід рослин-запилювачів інколи сягає $90 \%$, а то й $100 \%$ від загальної маси сіянців. Ефективні методи визначення статі сіянців актинідії до вступу їх у генеративну фазу розвитку (на 5-7-й рік після посіву) нині відсутні, тому питання пошуку критеріїв ранньої діагностики статі рослин актинідії й опрацювання методу її визначення є надзвичайно актуальним і має важливе теоретичне та практичне значення. На основі комплексного вивчення особливостей чоловічих і жіночих рослин Actinidia arguta (Siebold \& Zucc.) Planch. ex Miq. колекції Національного ботанічного саду ім. М. М. Гришка НАН України запропоновано метод діагностики статі сіянців у прегенеративний період їх розвитку. В основу методу ідентифікації статі A.arguta, що пропонують, покладено оброблення рослинних зразків хімічним реагентом, подальший аналіз результатів реакції та встановлення статі рослини за забарвленням зразків. Точність визначення сягає 95 \%, що вказує на високу ефективність і перспективність частого використання запропонованого експрес-методу визначення статі у прегенеративному періоді розвитку рослин. Застосування цього методу дає змогу визначити стать рослин уже в 2-3-річному віці.
\end{abstract}

Ключові слова: види роду Actinidia Lindl.; морфолого-анатомічна будова; пагони ліан; крохмаль.

Вступ. Дослідження, які стосуються проблем статевого диморфізму господарсько-цінних видів дводомних рослин, мають важливе теоретичне і прикладне значення, необхідні для опрацювання методів діагностики статі рослин у ювенільному періоді розвитку. Відповідно до еколого-гормонально-генетичної концепції детермінації статі в рослин (Chailakhian \& Khrianin, 1982) вплив екологічних чинників реалізується через вплив на ендогенну гормональну систему, яка взаємодіє з генетичним апаратом і зумовлює прояв статі в рослин.

Представники роду Actinidia Lindl. - це переважно дводомні рослини, i тому для створення сприятливих для перезапилення умов та високої продуктивності насаджень на ділянках під час садіння рекомендують ви- саджувати чоловічі та жіночі рослини у співвідношенні 1 до 5-7 (Shaitan et al., 1983; Ferguson \& Huang, 2007). Для цього використовують сортові рослини, розмножені вегетативно, тоді як рослини-запилювачі можуть бути вегетативного і насіннєвого походження. Численні дослідження свідчать, що за умов інтродукції саме сіянці краще пристосовуються до нових умов вирощування, вирізняються вищою адаптивною здатністю, підвищеною стійкістю до негативних чинників навколишнього середовища порівняно 3 вегетативно розмноженими рослинами. Актинідія - інтродуцент флори південносхідного азійського генетичного центру, тому за умов інтродукції рослин в Україну зі значно суворішими кліматичними умовами як рослини-запилювачі доцільно

Інформація про авторів:

Скрипченко Надія Василівна, канд. біол. наук, ст. науковий співробітник відділу акліматизації плодових рослин. Email: pandarija@gmail.com

Дзюба Оксана Іванівна, канд. біол. наук, ст. науковий співробітник відділу алелопатії. Email: dzjuba@nas.gov.ua

Короткіх Ліна Михайлівна, провідний інженер служби з питань трансферу технологій, інноваційної діяльності та інтелектуальної власності. Email: I.m.korotkikh@nas.gov.ua

Наталія Євгенівна Горбенко, канд. с.-г. наук, доцент, кафедра ботаніки, деревинознавства та недеревних ресурсів лісу. Email: nata.horbenko@gmail.com

Нужина Наталія Володимирівна, канд. біол. наук, ст. науковий співробітник інституту біології і медицини. Email: nuzhynan@gmail.com

Цитування за ДСтУ: Скрипченко Н. В., Дзюба О. І., Короткіх Л. М., Горбенко Н. Є., Нужина Н. В. Ідентифікація статі рослин актинідії гострої (Actinidia arguta (Siebold \& Zucc.) Planch. ех Miq.). Науковий вісник НЛтУ України. 2018, т. 28, № 6. С. 43-46.

Citation APA: Skrypchenko, N. V., Dzjuba, O. I., Korotkikh, L. M., Horbenko, N. Ye., \& Nuzhyna, N. V. (2018). The determination of hardy kiwi (Actinidia arguta (Siebold \& Zucc.) Planch. ex Miq.) plants gender. Scientific Bulletin of UNFU, 28(6), 43-46.

https://doi.org/10.15421/40280608 
використовувати особини насіннєвого походження. Для оптимальної організації селекційного процесу з культурою актинідії і підвищення його ефективності навпаки важливо вже в ювенільний період вибракувати чоловічі особини i, відповідно, значно зменшити затрати по догляду за селекційним фондом. До вступу сіянців актинідії в генеративний період розвитку, який починається на 5-7 рік після висіву, чоловічі та жіночі рослини не відрізняються між собою за морфологічними ознаками, а висаджувати рослини на постійне місце вирощування рекомендують у 2-3-х річному віці. Це ускладнює можливість використання рослин-запилювачів насіннєвого походження. Водночас, за літературними даними, вихід рослин-запилювачів під час насіннєвого розмноження може сягати $90 \%$, а інколи й 100 \% відносно загальної маси сіянців (Michurin, 1948; Skrypchenko \& Moroz, 2009; Shaitan et al., 1983).

На сучасному етапі досліджень відомим методом визначення статі рослин актинідії $є$ біохімічний метод кольорових осадів, коли витяжку з листків обробляють оцтово-кислим свинцем, а як контроль використовують витяжки 3 листків дорослих рослин із відомою статтю (Kolbasina, 2007). Недоліками цього способу $є$ його складність і тривалість виконання, потреба приладів для підготовки сировини, вартісних реактивів, можливість діагностики статі лише в дорослих рослин (5-7 років), низька точність $(65,0 \%)$ діагностики, бо можливі помилки через близькість відтінків забарвлення осадів. Відомий спосіб діагностики статі є дуже неточним також через те, що кольори осадів та їх інтенсивність змінюються залежно від фази розвитку рослини та моменту взяття проб для аналізу. До того ж метод кольорових осадів неможливо застосувати для ідентифікації статі рослин A.arguta з пурпуровим забарвленням.

Оскільки достовірні методи діагностики статі рослин актинідії допоки відсутні, то питання пошуку критеріїв ранньої діагностики статі рослин, опрацювання простих i доступних методів іiі визначення $є$ надзвичайно актуальним і має важливе теоретичне та практичне значення.

Метою дослідження є опрацювання експрес-методу діагностики статі сіянців у ювенільний період їх розвитку на основі комплексного анатомічного, біохімічного та гістохімічного вивчення однорічних пагонів різностатевих рослин видів роду Actinidia Lindl.

Матеріали та методи дослідження. Об'єктом дослідження були плодоносні рослини актинідії та сіянці віком від 1 до 7 років колекції Національного ботанічного саду (НБС) ім. М. М. Гришка НАН України: Actinidia arguta var. purpurea (Rehder) C. F. Liang ex Q. Q. Chang, A.arguta (Siebold \& Zucc.) Planch. ex Miq., A.kolomikta (Rupr. \& Maxim.) Maxim. Для анатомічних досліджень використовували середню частину однорічних пагонів жіночих та чоловічих рослин. Морфоанатомічні дослідження проводили 3 використанням світлооптичного мікроскопу NY-1. Якісний вміст крохмалю досліджували в однорічних пагонах рослин за методикою (Pausheva, 1988) 3 використанням розчину $\mathrm{I}_{2}-\mathrm{KI}$. Кількісний вміст крохмалю в рослинній сировині визначали спектрометричним методом (Ternynko, Tkachenko \& Burtseva, 2011). Дослідження проводили в різних фазах розвитку рослин упродовж 2010-2015 pр.

Результати дослідження та їх обговорення. Статевий диморфізм є пристосувальною ознакою рослин, на- бутою у процесі еволюції, яка пов'язана з фізіолого-біохімічною різноякісністю чоловічих і жіночих організмів. Аналіз літературних даних свідчить про неодноразові спроби дослідження статевого диморфізму та проблеми ранньої діагностики статі окремих видів роду Actinidia L. (Butnytskyi, 1975; Kolbasina, 2000; Litvinenko, Shpilevoi \& Maistrenko, 1994; Skrypchenko \& Moroz, 2009; Gill et al., 1998; Harvey et al., 1997). Було встановлені особливості чоловічих та жіночих рослин актинідії різної статі, і навіть запропоновані методи діагностики статі рослин, які вирізнялись значною трудомісткістю, малоефективністю практичного застосування.

Дослідження анатомічної будови однорічних пагонів чоловічих та жіночих рослин актинідії показали, що їх стебло формується на основі прокамбіальних пучків, $\epsilon$ типовим безпучковим (Tcyrendorzhieva, 2006; Li-jun et al., 1991). Однорічне стебло вкрите перидермою, під якою розміщена коленхіма та паренхімні клітини з потовщеними стінками, здерев'янілі луб'яні волокна представлені суцільним кільцем, добре розвинуті флоема та ксилема, паренхіма серцевини (рис. 1).

Під багаторядною, насиченою суберином перидермою, розміщена пластинчаста коленхіма та дрібні клітини корової паренхіми, заповнені хлоропластами. Провідна система відкрита колатеральна. Первинна флоема представлена суцільним кільцем здерев'янілих луб'яних волокон. Промені первинної ксилеми заходять у серцевину. Периферійна частина серцевини утворює перимедулярну зону. Серцевина складається 3 великих округлих або багатокутних паренхімних клітин, які з віком відмирають, що призводить до утворення в центрі пагона порожнини.

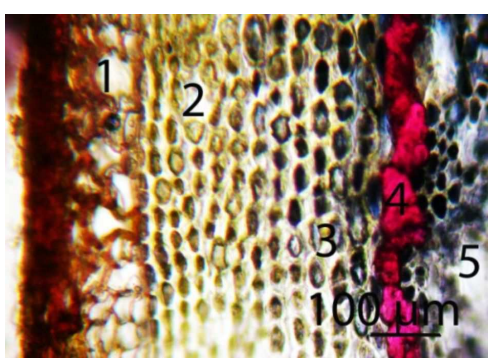

Рис. 1. Поперечний зріз однорічного пагона сорту 'Дон Жуан' (фрагмент): 1) перидерма, 2) коленхіма, 3) паренхіма, 4) луб'яні волокна, 5) флоема

Аналіз результатів дослідження однорічних пагонів актинідії виявив певну різницю в анатомічній будові пагонів різностатевих особин у межах виду-перидерма однорічних пагонів жіночих рослин краще розвинута, порівняно з чоловічими.

Дослідження динаміки вмісту крохмалю в однорічних пагонах рослин виявило зміну показників вмісту залежно від фази розвитку рослин та погодних умов. Було встановлено два піки його накопичення протягом року: перший - в жовтні після листопаду, другий - навесні на початку росту пагонів. Перший максимум пов'язаний з підготовкою рослин до зимівлі, оскільки запасні речовини відіграють значну роль у підвищенні стійкості рослин до дії стресових чинників. Під час зниження температури частина крохмалю гідролізується, i в клітинах накопичується цукор, який підвищує водоутримувальні сили колоїдів протопласту, збільшує кількість міцно зв'язаної води. Саме тому, навесні, на початку періоду вегетації, в пагонах актинідії відзначаємо незначний вміст крохмалю, а 3 початком росту пагонів 
(кінець квітня) спостерігаємо поступове його збільшення (таблиця).

Таблиця. Вміст крохмалю в пагонах чоловічих та жіночих рослин актинідії гострої (2010-2015 рр.), мг/мл

\begin{tabular}{|c|c|c|c|c|}
\hline \multirow{2}{*}{ Сорт, стать } & \multicolumn{4}{|c|}{ Дата } \\
\cline { 2 - 5 } & 25.01 & 25.02 & 25.03 & 25.04 \\
\hline 'Дон Жуан', О人 & 6,6 & 5,6 & 2,1 & 5,8 \\
\hline 'Київська крупноплідна',, & 7,6 & 5,2 & 2,5 & 4,1 \\
\hline
\end{tabular}

Наведені дані таблиці свідчать про те, що різниця в показниках між чоловічими і жіночими рослинами дослідних видів найбільш виражена саме в цей період розвитку (довжина молодих пагонів сягає 15-20 см). Тому подальші дослідження рослин актинідії проводили саме в цей період.

У дослідженнях різних видів актинідії, інтродукованих у НБС, спостерігали певну видоспецифічність накопичення крохмалю рослинами і зміни показників вмісту залежно від статі рослин. Так, на зрізах стебла A.kolomikta найбільше накопичення крохмалю відзначали у клітинах перимедулярної зони, менше його міститься в паренхімі радіальних променів та в шарі паренхіми кори, який прилягає до склеренхімних луб'яних волокон. У пагонах жіночих особин відзначали дещо більше крохмалю, ніж у чоловічих, який переважно зосереджений в клітинах перимедулярної зони і радіальних променях. У пагонах видів A.arguta крохмаль наповнює клітини перимедулярної зони, радіальних променів, флоеми і кори (рис. 2). Чітку різницю між особинами різної статі встановили в період максимального накопичення крохмалю на початку вегетації, різницю між пагонами чоловічих і жіночих рослин за вмістом крохмалю виявили найбільш істотною.

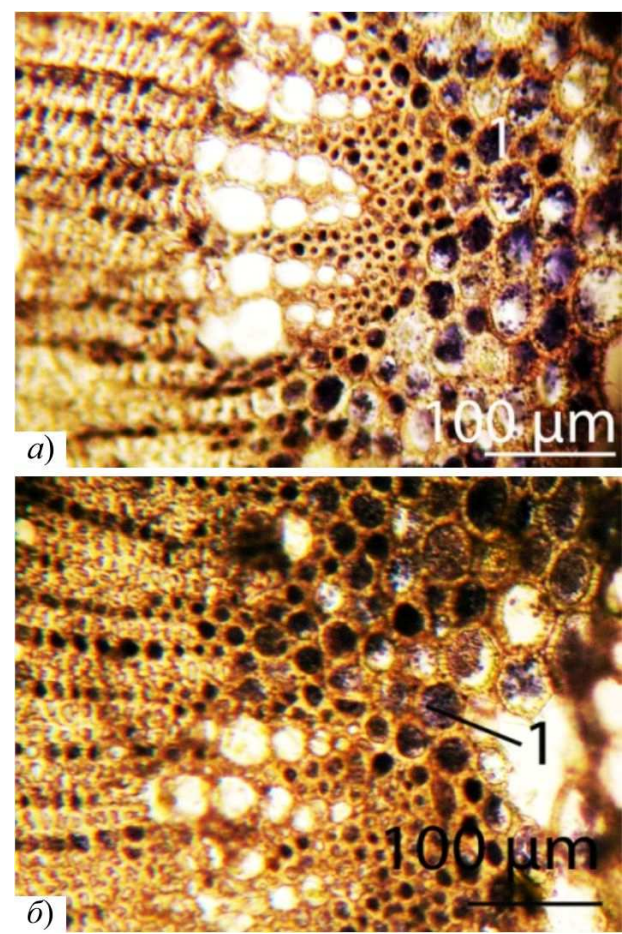

Рис. 2. Накопичення крохмалю в перимедулярній зоні пагонів актинідії гострої: а) чоловічих рослин, б) жіночих рослин: 1) крохмаль після оброблення розчином йоду

На основі проведених багаторічних досліджень запропоновано метод визначення статі сіянців актинідії із застосуванням якісної реакції на крохмаль розчином йоду (Skripchenko \& Dziuba, 2017). Перевагою цього методу є простота, легкість і мобільність виконання, доступність для широкого загалу садівників, можливість масового використання без будь-якої шкоди для рослин. Різницю в забарвленні спостерігали вже за 3 хв після нанесення реактиву. У чоловічих екземплярів забарвлення локалізоване у перимедулярній зоні, а в жіночих простягається через паренхіму радіальних променів до зовнішніх шарів.

Цей метод апробували на селекційних ділянках ботанічного саду. Його застосували під час визначення статі 350 сіянців різного віку A.arguta, який є найбільш перспективним для впровадження у промислове садівництво багатьох країн світу. Після досягнення сіянцями генеративного віку попередню діагностику було підтверджено на 95 \%, що вказує на високу ефективність i перспективність частого використання запропонованого експрес-методу під час визначення статі рослин актинідії в ювенільний період розвитку. Застосування цього методу дає змогу визначити стать рослин уже в 3річному віці та використати рослини 3 тичинковими квітками під час створення насаджень актинідії.

Висновки. Вперше розроблено i запатентовано експрес-метод діагностики статі рослин актинідії у прегенеративний період їх розвитку. Застосування його сприятиме поліпшенню селекційної роботи та використанню рослин-запилювачів актинідії насіннєвого походження під час закладення насаджень та значно зменшить затрати щодо дорощування селекційного матеріалу.

\section{Перелік використаних джерел}

Butnytskyi, Y. N. (1975). Poliarnost i fyzyoloho-byokhymycheskye osobennosty seksualyzatsyy nekotorykh dvudomnykh rastenyi. Abstract of Candidate Dissertation for Biology Sciences (03.00.12 - Plant Physiology). 28 p. [In Russian].

Chailakhian, M. Kh., \& Khrianin, V. N. (1982). Pol rastenii i ego gormonalnaia reguliatciia. Moscow: Nauka. 176 p.[in Russian].

Ferguson, A. R., \& Huang, G. H. (2007). Genetic Resources of Kiwifruit: Domestication and Breeding. Plant and Food Research, 3, 1-121.

Gill, G. P., Harvey, C. F., Gardner, R. C., Fraser, L. G. (1998). Development of sex-linked PCR markers for gender identification in Actinidia. Theor. Appl. Genet, 97(3), 439-445.

Harvey, C. F., Gill, G. P., Fraser, L. G., McNeilage, M. A. (1997). Sex determination in Actinidia. 1. Sex-linked markers and progeny sex ratio in diploid A-chinensis. Sex. Plant Reprod., 10(3), 149-154.

Kolbasina, E. I. (2000). Opredelenie pola v semennom potomstve aktinidii. 2-i s'ezd VOGIS, (pp. 149-150). St. Peterburg. [In Russian].

Kolbasina, E. I. (2007). Aktinidiia, limonnik: Posobie dlia sadovodovliubitelei. Moscow: Izd-vo "Niola Press", Izd. Dom "IuNIONpablik". 176 p. [In Russian].

Li-jun, W., You-min, Zh., Yan, Zh., et al. (1991). Studies on the secondary vascular tissue in the stem of Actinidia arguta (Sieb. et Zucc.) Planch ex Miquel. Bulletin of Botanical Research, 11(1), 79-83.

Litvinenko, N. M., Shpilevoi, B. E., \& Maistrenko, O. V. (1994). Soderzhanie karotinoidov v listiakh raznopolykh rastenii vidov roda Actinidia Lindl. Introduktciia i akklimatizatciia rastenii, 21, 87-89. [In Russian].

Michurin, I. V. (1948). Aktinidiia. In 3 vol, (pp. 569-616). Moscow: OGIZ. [In Russian].

Pausheva, Z. P. (1988). Praktikum po tcitologii rastenii. Moscow: Agropromizdat. 271 p. [In Russian].

Shaitan, I. M., Moroz, P. A., Klimenko, S. V., et al. (1983). Introduktciia i selektciia iuzhnykh i novykh plodovykh rastenii. Kyiv: Naukova dumka. 216 p. [In Russian].

Skripchenko, N. V., \& Dziuba, O. I. (2017). Sposib viznachennia stati roslin aktinidii A. arguta. Patent Ukrainy № 122529, A01G 17/00. u201708315. Zayavl. 14.08.2017; opubl. 10.01.2018. Biul. № 1. [In Ukrainian]. 
Skrypchenko, N. V., \& Moroz, P. A. (2009). Statevyi dymorfizm vydiv rodu ACTINIDIA Lindl. Introduktsiia roslyn, (pp. 50-58). [In Ukrainian].

Tcyrendorzhieva, O. Zh. (2006). Anatomiia steblia lian Sakhalina i Kuril. Abstract of Candidate Dissertation for Biology Sciences (03.02.07 - Genetics). Ulan-Ude. 21 p. [In Russian].
Ternynko, I. I., Tkachenko, V. H., \& Burtseva, O. V. (2011). Sposib kilkisnoho vyznachennia krokhmaliu v roslynnii syrovyni. Patent Ukrainy № 65517, A01G 1/00. u 201105759. Zayavl. 06.05.2011; opubl. 12.12.2011. Biul. № 23. [In Ukrainian].

\section{Н. В. Скрипченко1, О. И. Дзюба 1 , Л. М. Коротких ${ }^{2}$, Н. Є. Горбенко ${ }^{3}$ Н. В. Нужина \\ ${ }^{1}$ Национальный ботанический сад им. Н. Н. Гришко, НАН Украины, г. Киев, Украина ${ }^{2}$ Институт физико-органической химии им. Л. М. Литвиненко, НАН Украины, г. Киев, Украина \\ ${ }^{3}$ Национальный лесотехнический университет Украины, г. Львов, Украина ${ }^{4}$ Учебно-научный цеентр "Институт биологии и медицины" КНУ им. Тараса Шевченко, г. Киев, Украина \\ ИДЕНТИФИКАЦИЯ ПОЛА РАСТЕНИЙ АКТИНИДИИ ОСТРОЙ (ACTINIDIA ARGUTA (SIEBOLD \& ZUCC.) PLANCH. EX MIQ.)}

Актинидия - это двудомная культура, и для обеспечения высокой производительности ее насаждений на участках необходимо одновременно высаживать мужские и женские растения в соотношении 1 к 5-7. Сортовые женские растения для посадки получают только при вегетативном размножении, в то время как мужские растения-опылители могут быть как вегетативного, так и семенного происхождения. Многочисленные исследования показывают, что сеянцы лучше приспосабливаются к новым условиям произрастания, отличаются высокой адаптивной способностью, повышенной устойчивостью к негативным факторам окружающей среды по сравнению с вегетативно размноженными растениями. По литературным данным, выход растений-опылителей иногда достигает $90 \%$, а то и $100 \%$ от общей массы сеянцев. Методы определения пола сеянцев актинидии до вступления их в генеративную фазу развития (на 5-7-й год после посева) в настоящее время отсутствуют, поэтому вопрос поиска критериев ранней диагностики пола растений актинидии и разработки метода ее определения является чрезвычайно актуальным и имеет важное теоретическое и практическое значение. На основе комплексного изучения особенностей мужских и женских растений Actinidia arguta (Siebold \& Zucc.) Planch. ex Miq. коллекции Национального ботанического сада им. Н. Н. Гришко НАН Украины разработан метод диагностики пола сеянцев в прегенеративный период их развития. В основу предложенного метода идентификации пола A.arguta положена обработка растительных образцов химическим реагентом, дальнейший анализ результатов реакции и установление пола растения по окраске образцов. Точность определения достигает $95 \%$, что указывает на высокую эффективность и перспективность широкого использования предложенного экспресс-метода определения пола в прегенеративном периоде развития растений. Применение данного метода позволяет определить пол растений уже в 2-3-летнем возрасте.

Ключевые слова: виды рода Actinidia Lindl.; морфолого-анатомическое строение; побеги лиан; крахмал.

N. V. Skrypchenko', O. I. Dzjuba', L. M. Korotkikh², N. Ye. Horbenko ${ }^{3}$, N. V. Nuzhyna ${ }^{4}$

${ }^{I}$ M. M. Gryshko National botanical garden, NAS Ukraine, Kyiv, Ukraine

${ }^{2}$ L. M. Litvinenko Institute of Physical-Organic Chemistry and Coal Chemistry, NAS of Ukraine, Kyiv, Ukraine

${ }^{3}$ Ukrainian National Forestry University, Lviv, Ukraine

${ }^{4}$ Educational and Scientific Center "Institute of Biology and Medicine" of Taras Shevchenko National University of Kyiv, Kyiv, Ukraine

THE DETERMINATION OF HARDY KIWI (ACTINIDIA ARGUTA (SIEBOLD \& ZUCC.) PLANCH. EX MIQ.) PLANTS GENDER

The problem of gender differentiation and the methods and criteria search for its diagnosis in dioecious plants of the Actinidia at an early stage of development is an extremely important item. It is important both for gardening practice and for successful breeding work with this culture. The morpho-anatomical studies of Actinidia arguta one-year male and female plants twigs were performed using NY-1 light-optical microscope. The qualitative content of starch was studied in one-year twigs of plants using of an iodine solution. The study of the starch content dynamics in the one-year twigs of male and female plants has revealed a variation of the content indicators that depends on the plant development phase and the weather conditions. The two peaks of its accumulation during the year have been defined (the first one is in October, after defoliation, and the second one - is in the spring at the beginning of the twigs growth). The difference in the indices between male and female plants was represented mostly during the second maximum (the length of young twigs reached 15-20 cm). The method for the Actinidia Lindl. seedlings gender determining with the use of qualitative reaction on starch (iodine solution) on the basis of the long-term researches conducted on the male and female Actinidia Lindl. plants, the successful testing on the seed origin Actinidia Lindl. plants was proposed. The difference in colour is observed in 3 minutes after the reagent application. The colour is localized in the perimedullary zone in male individuals, while in female individuals it extends through the parenchyma of the xylem rays to the external layers. The advantage of this method is the simplicity and the portability of the implementation, the availability to the general public of the gardeners and the possibility of mass use without causing any harm to the plants. The application of this method will contribute to the improvement of the breeding work and the use of pollinating plants of Actinidia Lindl. of the seed origin at planting and significantly reduce the raising cost for the selection material.

Keywords: vines; gender; xylem; iodine; starch. 